\title{
Synthesis, Crystal Structure and Thermolysis of Cadmium Perchlorate Complex with Hexamethylenetetramine
}

\author{
Chandra Prakash Singh ${ }^{1(\mathbb{D})}$, Abhishek Singh ${ }^{1(\mathbb{D})}$, Nibha ${ }^{2(\mathbb{D})}$, Constantin G. Daniliuc ${ }^{3(\mathbb{D})}$, \\ Gurdip Singh ${ }^{2}$ (i), Devendra Pratap Rao ${ }^{4}$ (D)

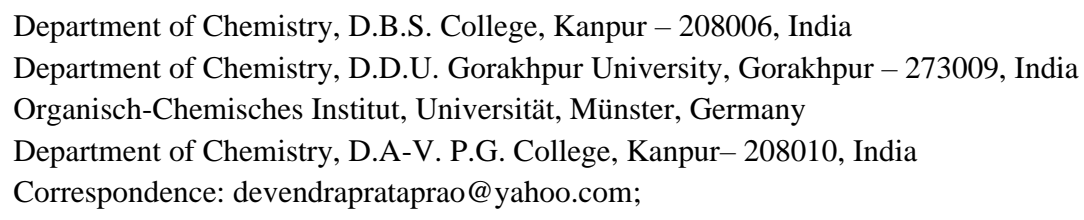

Received: 15.09.2020; Revised: 4.11.2020; Accepted: 10.11.2020; Published: 15.11.2020

\begin{abstract}
The complex of cadmium perchlorate, $\left[\mathrm{Cd}(\mathrm{HMTA})_{2}\left(\mathrm{H}_{2} \mathrm{O}\right)_{4}\right]\left(\mathrm{ClO}_{4}\right)_{2} \bullet 2 \mathrm{H}_{2} \mathrm{O}$ was synthesized by the reaction with hexamethylenetetramine (HMTA). C, H, N analyses, FT-IR, and X-ray crystallography were used to characterize the obtained complex. TG in the static air, simultaneous thermogravimetry-derivative thermogravimetry (TG-DTG), and differential scanning calorimetry (DSC) in streaming nitrogen atmosphere were evolved for thermal decay of prepared cadmium complex. To evaluate the reaction with quick warming, explosion delay measurements were attempted. The model-free isoconversional and model-fitting kinetic methodologies were applied to isothermal TG data for kinetic examination of the complex's thermal decomposition. At higher temperatures, the complex explodes to synthesize highly thermally stable residue most closely resembles cadmium oxide.
\end{abstract}

Keywords: hexamethylenetetramine; kinetics; thermolysis; isothermal TG; X-ray crystallography.

(C) 2020 by the authors. This article is an open-access article distributed under the terms and conditions of the Creative Commons Attribution (CC BY) license (https://creativecommons.org/licenses/by/4.0/).

\section{Introduction}

Hexamethylenetetramine (HMTA) or tetraazaadmantane (taad), commercially known as urotropine having four nitrogen atoms at corners of a tetrahedron, is a ligand of polycyclicploydentate type. HMTA behaves as a monodentate or bidentate ligand [1,2] and exhibits non-chelating behavior [2,3]. A. A. Dalvi et al. have used HMTA as a strong chelating agent for platinum and rhodium at the same time [4] HMTA when complexed with a transition metal or hydrogen-bonded with coordinated water [5,6] having the oxidizing group as a counter anion $\left(\mathrm{NO}_{3}{ }^{-}\right.$or $\left.\mathrm{ClO}_{4}^{-}\right)$exhibits the properties of stable high energetic compounds $\left(\mathrm{HEC}_{\mathrm{s}}\right)$ and undergo self-propagative exothermic thermal decomposition. As the sensitivity parameters are concerned, such type of metal amine perchlorate complexes lies between primary and secondary explosives [7]. In explosives, propellants, and pyrotechnics, transition metal complexes which are energetic are used. These complexes [8-12] behave as a burning rate promoter for propellants. In addition, at elevated temperatures, these complexes provide ultrafine metal oxides which may find applications in gas sensors, photocatalysis, self-cleaning [13], anode material for lithium-ion battery [14], inorganic electrochromic films [15], and in composite solid propellants as burning rate modifier [16].

Homo- and heterometallic compounds derived from s-indacene shift the peak temperature to the left and increase released heat during thermal decomposition of ammonium 
perchlorate [17]. Cobalt complex of 2,6-diamino-3,5-dinitropyrazine-1-oxide exhibited excellent catalytic activity on the thermal decomposition of ammonium perchlorate [18]. The low-temperature molar heat capacities and thermodynamic properties (TG, DSC) of a crystalline complex of copper perchlorate are coordinated with imidazole $\mathrm{Cu}\left(\mathrm{C}_{3} \mathrm{~N}_{2} \mathrm{H}_{4}\right)_{4}\left(\mathrm{ClO}_{4}\right)_{2}$ [19] and a crystalline rare-earth complex $\mathrm{Er}_{2}\left(\mu_{2}-\mathrm{Gly}\right)_{6}\left(\mathrm{H}_{2} \mathrm{O}\right)_{4} \bullet \mathrm{Na}_{2}\left(\mathrm{ClO}_{4}\right)_{8}\left(\mathrm{H}_{2} \mathrm{O}\right)_{2} \bullet 4 \mathrm{H}_{2} \mathrm{O}$ [20] has been recently studied. The complex $\left[\mathrm{Fe}(\mathrm{HMTA})_{2}\left(\mathrm{H}_{2} \mathrm{O}\right)_{3}\left(\mathrm{NO}_{3}\right)\right]\left(\mathrm{NO}_{3}\right)_{2} \bullet 2 \mathrm{H}_{2} \mathrm{O}$ has been used as a precursor for crystalline nanoparticles of $\alpha-\mathrm{Fe}_{2} \mathrm{O}_{3}$ [21]. $\mathrm{Co}$ (II) and $\mathrm{Zn}$ (II) complexes of hexamethylenetetramine were found as a single source precursors for nanoparticles of $\mathrm{Co}_{3} \mathrm{O}_{4}$ and $\mathrm{ZnO}$ [22]. $\mathrm{Co}$ (II) complex with HMTA and succinic acid was taken as ligands exhibit increased antibacterial test in comparison to the parent ligands [23]. [Ni(HMTA $)_{2}(\mathrm{NCS})_{2}\left(\mathrm{H}_{2} \mathrm{O}\right)_{2}$ has been synthesized, characterized, and found to be moderate antibacterial [24]. At present, strong attention is being given to the thermal decomposition studies of energetic metal amine perchlorate complexes [25-28]. CdO nanoparticles have been obtained by calcination of cadmium HMTA complex $\left[\left\{\mathrm{Cd}(\mathrm{HMTA})\left(\mathrm{NO}_{3}\right)_{2}\left(\mathrm{H}_{2} \mathrm{O}\right)_{2}\right\}_{\mathrm{n}}\right]$ at $500^{\circ} \mathrm{C}$ [29]. The compounds $\left[\mathrm{Cd}_{1.5} \mathrm{I}_{3}(\mathrm{HMTA}) \cdot \mathrm{H}_{2} \mathrm{O}\right]$ and $\left[\mathrm{CdI}_{2}(\mathrm{HMTA}) \cdot \mathrm{H}_{2} \mathrm{O}\right]$ were formed, characterized, and have been found to show luminescence activity [30]. In this work dichlorotetrakis(1-vinylimidazole)cadmium(II), $\left.\left[\mathrm{CdCl}_{2} \text { (vim) }\right)_{4}\right]$ complex was synthesized using 1-vinylimidazole (vim) ligand and $\mathrm{CdCl}_{2}$ [31]. Synthesis, structure, and luminescent properties have been investigated for cadmium complex with 1,3-bis(1,2,4-triazol-1yl)propane [32]. Mononuclear and dinuclear species of (1,10-phenanthroline)bis(4formylbenzoate) cadmium(II) complex are found to be fluorescent [33]. Cadmium complex containing azobenzene carboxylato co-ligands has been found as a photoswitching agent [34]. Synthesis, structural diversity, luminescent properties, and antibacterial effects of cadmium(II) coordination compounds with bis(1,2,3-benzotriazol-1-yl) alkanes have been studied by R.D. Marchenko et al. [35]. Cadmium(II) complex with ligand [N-(3-acetylphenylcarbamothioyl)2- chloroacetamide] found to be antibacterial agent [36]. [Cd (aminotetrazole) $\left(\mathrm{CH}_{3} \mathrm{COO}\right)$ $\left(\mathrm{H}_{2} \mathrm{O}\right)$, displays good chemotherapeutic potential with reduced nephrotoxicity compared to cisplatin [37]. Structure, DFT studies, Hirshfeld surface analysis, and antimicrobial activity for cadmium complex of sulfathiazole dihydrate with secondary ligand pyridine were studied [38]. Compounds $\left\{[\mathrm{hmt}]\left[\mathrm{Cu}_{3} \mathrm{Br}_{3}\right]\left[\mathrm{H}_{2} \mathrm{O}\right]\right\} \mathrm{n} 2$ has been found to have good photocatalytic degradation properties for the dye methylene blue. It also exhibited a high-sensitivity and high-selectivity fluorescence response to $\mathrm{Cr}^{3+}[39,40]$. Earlier, we have analyzed the TG-DSC, crystal structure, impact, and friction sensitivity of lanthanum nitrate with HMTA [41]. This paper depicts the synthesis, characterization, and thermal behavior of cadmium perchlorate complex with HMTA as monodentate ligands.

\section{Materials and Methods}

\subsection{Materials.}

Cadmium carbonate (s.d.fine; impurity limit $0.65 \%$ ), perchloric acid (s.d. fine; $60 \%$ ), hexamethylenetetramine (Merck; 99\%)), all of AR grade were used as received.

\subsection{Preparation.}

Two steps synthesis was involved in the complex formation. In the $1^{\text {st }}$ step, $\mathrm{Cd}\left(\mathrm{ClO}_{4}\right)_{2} \cdot 6 \mathrm{H}_{2} \mathrm{O}$ was obtained by the reaction of the metal carbonate with $60 \%$ perchloric acid, followed by recrystallization. In the $2^{\text {nd }}$ step, the mixture of metal perchlorate and 
hexamethylenetetramine (HMTA) in an aqueous medium was reacted together in the stoichiometric amount at room temperature. The solution was filtered off. The filtrate was kept in a vacuum to afford colorless crystals, which were washed with distilled water and dried in desiccators over dried calcium chloride.

\subsection{Characterization.}

\subsubsection{Spectral characterization.}

The characterization of complexes was done by elemental analyses $(\mathrm{C}, \mathrm{H}, \mathrm{N}$; Elementar Vario EL III), IR [42-44] (Thermo Nicolet, Avatar 370 FT-IR spectrometer; KBr beam splitter, resolution $4.0 \mathrm{~cm}^{-1}$ ), and thermogravimetry (Table1).

\subsubsection{X-ray crystallographic study.}

Crystal of the complex, $\left\{\left[\mathrm{Cd}(\mathrm{HMTA})_{2}\left(\mathrm{H}_{2} \mathrm{O}\right)_{4}\right]\left(\mathrm{ClO}_{4}\right)_{2} \cdot 2 \mathrm{H}_{2} \mathrm{O}\right\}$ with diameter $0.23 \times$ $0.16 \times 0.08 \mathrm{~mm}$ was set up on a Nonius Kappa CCD diffractometer. Rotating anode generator, Nonius FR591 is used for statistics collection at low temperature, 223(2)K. Data collection collects (Nonius B. V.; 1998) and data reduction [45] applications are used for data collection and reduction, respectively. For absorption correction, DENZO-SMN [46] is used.

Specific methods (SHELXS-97) have proven the structure [47]. For nonhydrogen atoms, the complete matrix, the least square approach on $\mathrm{F}^{2}$ was used. The range of $\theta$ for data collection exists from 4.11 to $26.37^{\circ}$. Anisotropic thermal parameters for nonhydrogen atoms have been refined and produced an R-value of 0.034 . The crystal structure (graphic did with SCHAKAL, made in XP with $30 \%$ probability) [48] of the desired complex is given in Figure 1.

In Table 2, information on crystal data and refinement are given. Table 3 contains selected bond lengths and bond angles.

\subsection{Thermal analysis.}

Thermogravimetry in static air with a heating rate of $10^{\circ} \mathrm{C} \mathrm{min}^{-1}$ (figure 2) was recorded using $20 \mathrm{mg}$ sample mass on indigenously fabricated TG equipment [49]. Simultaneous TGDSC traces have been acquired in flowing nitrogen atmosphere (sample mass $2.845 \mathrm{mg}$; heating rate $10{ }^{\circ} \mathrm{C} \min ^{-1} ; \mathrm{N}_{2}$ flow rate $100 \mathrm{~mL} \mathrm{~min}^{-1}$ ) on Perkin Elmer, Diamond TG-DSC equipment (figures 3 and table 4). DSC was recorded in an inert atmosphere $\left(\mathrm{N}_{2}\right.$ gas, flow rate of $100 \mathrm{~mL} \mathrm{~min}^{-1}$ ) with sample mass $9.2 \mathrm{mg}$ at a heating rate of $10^{\circ} \mathrm{C} \mathrm{min}$ (figures 3 , table 4).

Isothermal TG curves were registered at five different temperatures $(200,210,220$, 230 , and $240^{\circ} \mathrm{C}$ ) for $30 \%$ mass loss (figure 4 ). This was performed on the same indigenous developed TG apparatus, as previously described. The sample mass taken was $10 \mathrm{mg}$.

Kinetics of decomposition has been explored utilizing isothermal TG data applying model-fitting (table 5) [50] and isoconversional method [51,52]. Figure 5 shows changes inactivation energy with the extent of conversion, $\alpha$. Explosion delay experiment (sample mass $10 \mathrm{mg}$ ) has been performed utilizing tube furnace technique [54], at temperatures 280, 300, 320,340 , and $360^{\circ} \mathrm{C}$ (table 6) within the experimental limit of $\pm 1^{\circ} \mathrm{C}$ given in figure 5 .

Equal sizes of ignition tubes $(4.0 \mathrm{~cm}$ long and $0.4 \mathrm{~cm}$ diameter) were used. Time has been recorded between the insertion of the ignition tube into the furnace and the explosion of the sample. $\left(D_{E}\right)$ data were fitted in the Arrhenius equation shown in Eq. (1), 


$$
D_{E}=A \exp E^{*} / R T
$$

where A represents the Arrhenius factor; $E^{*}$ represents the activation energy for the explosion; T represents absolute temperature, and $R$ represents the universal gas constant. A plot of ln DE vs $1 / T$ is exhibited in figure 6 . Table 6 presents the different kinetic parameters of the explosion.

\section{Results and Discussion}

Elemental data $(\mathrm{C}, \mathrm{H}, \mathrm{N})$ given in table 3 show a great agreement among the calculated and observed value of mass percentage of $\mathrm{C}, \mathrm{H}$, and $\mathrm{N}$, which support the molecular formula of the complex. In the FT-IR spectral data (table 1), absorption frequencies at 508 and $626 \mathrm{~cm}^{-}$ ${ }^{1}$ have been assigned for $v(\mathrm{Cd}-\mathrm{N})$ and $v(\mathrm{Cd}-\mathrm{O})$ stretching. The peak at $1087 \mathrm{~cm}^{-1}$ confirms the presence of ionic $\mathrm{ClO}_{4}^{-}$(unligated). Other spectral peaks provided in table 1 are according to the standard text.

The obtained complex has a monoclinic crystal system within the space group $\mathrm{P} 2{ }_{1} / \mathrm{C}$ no.14 $(\mathrm{Z}=2)$. From the molecular structure of the complex given in figure 1, it is confirmed that cadmium ion is six-fold coordinated, in which $\mathrm{N}$ and $\mathrm{O}-$ atoms are involved.

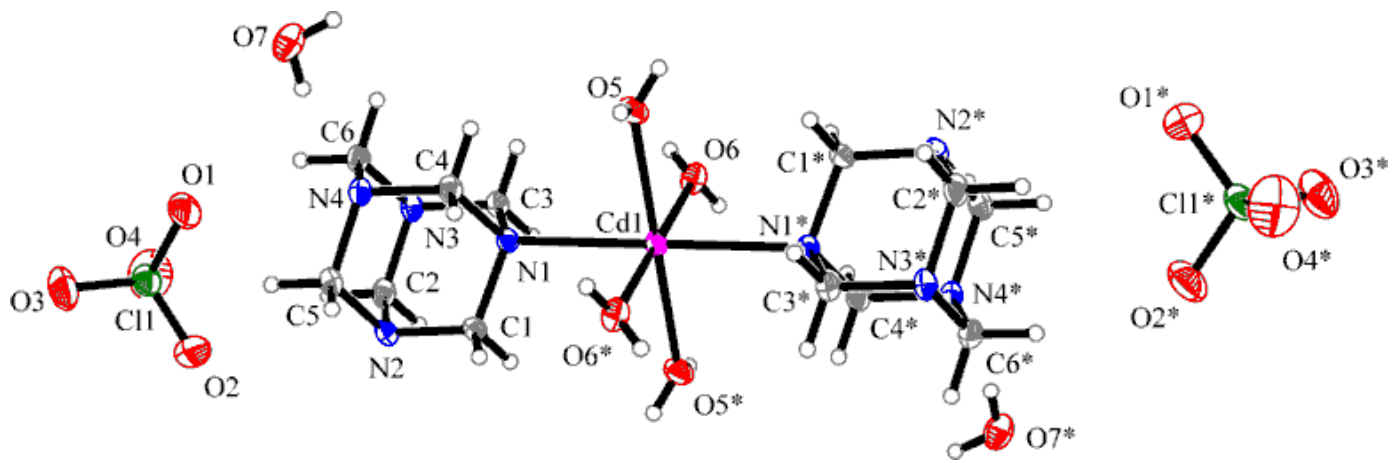

Figure 1. Crystal structure of the complex.

Out of six atoms, four are $\mathrm{O}$-atoms of four water molecules $\left(\mathrm{O} 5, \mathrm{O}^{*}, \mathrm{O} 6\right.$, and $\left.\mathrm{O6}^{*}\right)$, and two are $\mathrm{N}$-atoms of two HMTA moiety ( $\mathrm{N} 1$ and $\mathrm{N} 1 *) . \mathrm{Cd}-\mathrm{O}(5)$ and $\mathrm{Cd}-\mathrm{O}\left(5^{*}\right)$ bond length are the same $(2.286 \AA$ ) but slightly shorter than Cd-O6 and Cd-O6* bond length $(2.291 \AA)$,

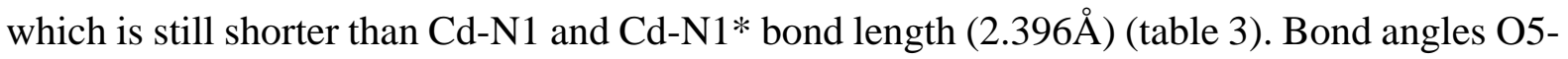
Cd-O5*, O6-Cd-O6*, and N1-Cd-N1* are all $180^{\circ}$ but angles O5-Cd-O6*, O6*-Cd-N1*, N1*Cd-O5*, O5*-Cd-O6, O6-Cd-N1, and N1-Cd-O5 are all close to $90^{\circ}$ but not exactly $90^{\circ}$ (table $3)$. Thus, the complex shows a distorted octahedral geometry.

Table 1. IR frequencies and elemental analysis data for the complex.

\begin{tabular}{c|c|c|c} 
Assignments & $\begin{array}{c}\text { IR } \\
\mathbf{v} / \mathbf{c m}^{-1}\end{array}$ & Element & $\begin{array}{c}\text { \%, Obs. / } \\
\text { (cald.). }\end{array}$ \\
\hline $\begin{array}{c}\text { Ionic } \\
\text { perchlorate }\end{array}$ & 626 & $\mathrm{~N}$ & $\begin{array}{c}15.88 \\
(16.0)\end{array}$ \\
\hline $\mathrm{M}-\mathrm{N}, \mathrm{M}-\mathrm{O}$ & 445,507 & $\mathrm{C}$ & $\begin{array}{c}20.33 \\
(20.57)\end{array}$ \\
\hline $\mathrm{CH}_{2}$ rocking & 776 & $\mathrm{H}$ & $\begin{array}{c}5.96 \\
(5.14)\end{array}$ \\
\hline $\mathrm{C}-\mathrm{H}$ str. $_{\mathrm{ClO}_{4}-}^{-}$ & 2882,2935 & & \\
\hline $\mathrm{C}-\mathrm{H}$ def. & 1087 & & \\
\hline O-H str. & 1466 & & \\
\hline $\mathrm{C}-\mathrm{N}$ str. & 99959,1021 & &
\end{tabular}


Two uncoordinated water molecules are also involved in the crystal lattice. Bond length data (table 3 ) reveals that the two $\mathrm{ClO}_{4}{ }^{-}$which are although uncoordinated to $\mathrm{Cd}^{++}$- metal ion, remain close to cadmium and HMTA moiety. Table 3 exhibits the rest selected bond lengths and bond angles. Atomic coordinates, equivalent isotropic, and anisotropic displacement parameters, along with hydrogen coordinates, are tabulated in the supplementary material (tables 1-3).

Table 2. Crystal parameters and refinement parameters for cadmium hexamethylenetetramine perchlorate

\begin{tabular}{l|l}
\multicolumn{2}{c}{ complex $(\mathrm{CHPC})}$. \\
$\mathrm{C}_{12} \mathrm{H}_{36} \mathrm{Cd} \mathrm{Cl}_{2} \mathrm{~N}_{8} \mathrm{O}_{14}$ & Empirical formula \\
\hline 699.79 & Formula weight \\
\hline $223(2) \mathrm{K}$ & Temperature \\
\hline $0.71073 \AA$ & Wavelength \\
\hline $2,1.832 \mathrm{Mg} / \mathrm{m} 3$ & Z, Calculated density \\
\hline $0.23 \times 0.16 \times 0.08 \mathrm{~mm}$ & Crystal size \\
\hline monoclinic, $\mathrm{P} 21 / \mathrm{c}(\mathrm{No} .14)$ & Crystal system, space group \\
\hline $\mathrm{a}=8.0031 / 1 \AA$ & Unit cell dimensions \\
$\mathrm{b}=19.2897 / 4 \AA \mathrm{A}=103.394(1)^{\circ}$ & \\
$\mathrm{c}=8.4481 / 2 \AA$ & \\
\hline $1268.72(4) \AA 3$ & Volume \\
\hline $1.152 \mathrm{~mm}-1$ & Absorption coefficient \\
\hline 716 & F(000) \\
\hline 4.11 to $26.37^{\circ}$ & Theta range for data collection \\
\hline$-9<=\mathrm{h}<=9,-22<=\mathrm{k}<=24,-10<=1<=10$ & Limiting indices \\
\hline $6908 / 2543[\mathrm{R}($ int $)=0.034]$ & Reflections collected / unique \\
\hline $98.3 \%$ & Completeness to theta $=26.37$ \\
\hline Semi-empirical from equivalents & Absorption correction \\
\hline 0.9135 and 0.7775 & Max. and min. transmission \\
\hline Full-matrix least-squares on F2 & Refinement method \\
\hline $2543 / 136 / 239$ & Data / restraints / parameters \\
\hline 1.061 & Goodness-of-fit on F2 \\
\hline $\mathrm{R} 1=0.0345$, wR2 $=0.0774$ & Final R indices [I>2s(I)] \\
\hline $\mathrm{R} 1=0.0393$, wR2 $=0.0807$ & R indices (all data) \\
\hline 0.854 and -0.539 e. $\AA-3$ & Largest diff. peak and hole \\
991077 & CCDC No. \\
\hline &
\end{tabular}

Table 5 glimpses the weight loss and the nature of the decomposition as depicted by the DSC curve. TG curve of the complex taken in a static air atmosphere (figure 2) and in a flowing nitrogen atmosphere (figure 3) shows that the complex decomposes in three steps.

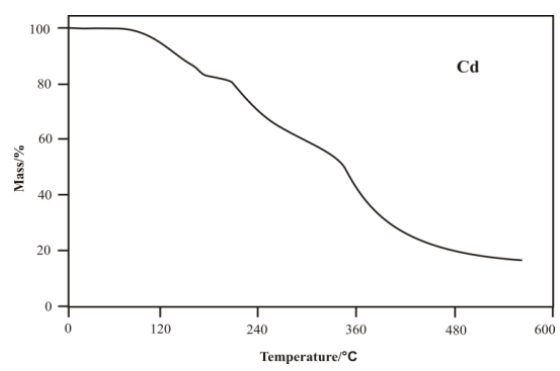

Figure 2. TG curve of complex in static air atmosphere.

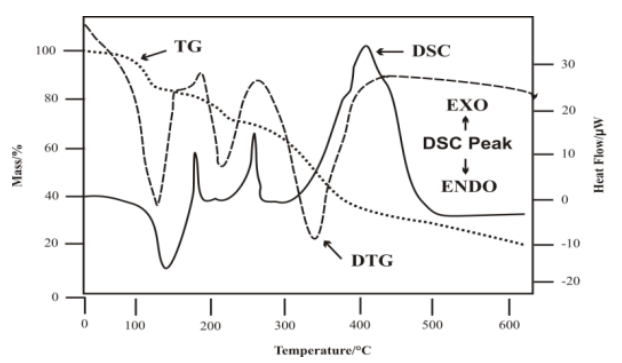

Figure 3. TG-DSC curve of complex in flowing $\mathrm{N}_{2}$ atmosphere. 
Table 3. Bond lengths and bond angles for the complex.

\begin{tabular}{|c|c|c|c|c|c|}
\hline Length & Bond & Angle & Bond & Angle & Bond \\
\hline $\begin{array}{l}2.286 / 3 \\
2.286 / 3 \\
2.291 / 3 \\
2.291 / 3 \\
2.396 / 2 \\
2.396 / 2 \\
1.408 / 4 \\
1.417 / 5 \\
1.433 / 5 \\
1.435 / 5 \\
1.407 / 15 \\
1.415 / 14 \\
1.417 / 14 \\
1.429 / 14 \\
1.488 / 4 \\
1.489 / 4 \\
1.494 / 4 \\
1.467 / 4 \\
1.475 / 4 \\
1.481 / 4 \\
1.469 / 4 \\
1.469 / 4 \\
1.478 / 4 \\
1.467 / 4 \\
1.468 / 4 \\
1.473 / 4 \\
0.9800 \\
0.9800 \\
0.9800 \\
0.9800 \\
0.9800 \\
0.9800 \\
0.9800 \\
0.9800 \\
0.9800 \\
0.9800 \\
0.9800 \\
0.9800 \\
0.77 / 2 \\
0.77 / 2 \\
0.77 / 2 \\
0.768 / 19 \\
0.77 / 2 \\
0.77 / 2\end{array}$ & 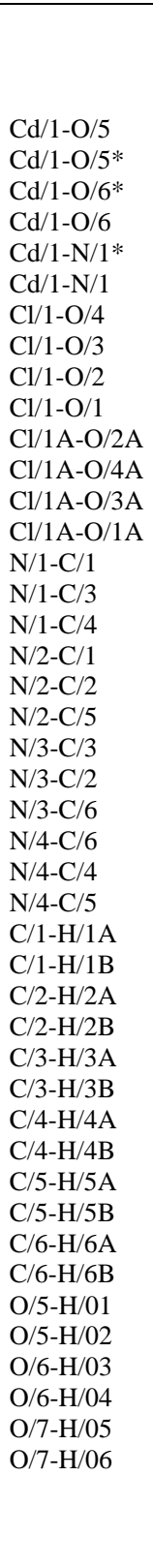 & $\begin{array}{l}180.00 / 9 \\
89.23 / 10 \\
90.77 / 10 \\
90.77 / 10 \\
89.23 / 10 \\
180.000 / 1 \\
85.90 / 9 \\
94.10 / 9 \\
86.85 / 9 \\
93.15 / 9 \\
94.10 / 9 \\
85.90 / 9 \\
93.15 / 9 \\
86.85 / 9 \\
180.000 / 1 \\
111.8 / 3 \\
110.2 / 3 \\
110.6 / 3 \\
109.3 / 4 \\
109.2 / 3 \\
105.5 / 4 \\
115 / 2 \\
111 / 2 \\
110 / 2 \\
106 / 2 \\
102.2 / 19 \\
112 / 2 \\
107.8 / 2 \\
107.7 / 2 \\
107.5 / 2 \\
108.40 / 18 \\
111.28 / 18 \\
113.98 / 18 \\
108.2 / 3 \\
108.4 / 3 \\
108.6 / 3 \\
108.4 / 3 \\
108.1 / 3 \\
108.3 / 3 \\
108.7 / 3 \\
108.4 / 3 \\
108.7 / 3 \\
112.1 / 3 \\
109.2 \\
109.2 \\
109.2 \\
109.2 \\
107.9 \\
112.0 / 3 \\
109.2 \\
\end{array}$ & 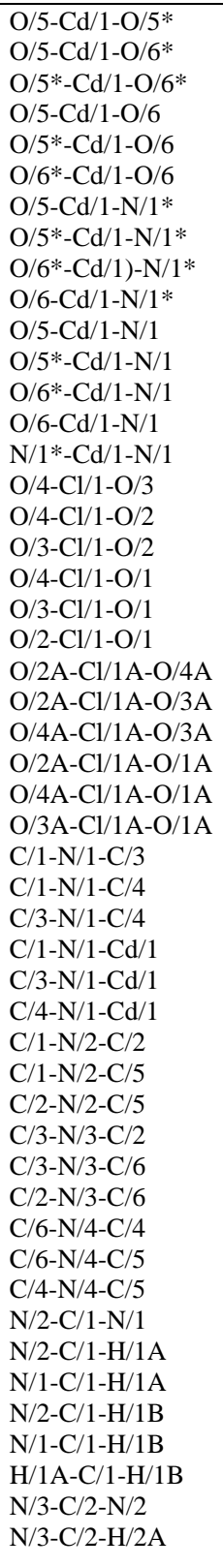 & $\begin{array}{l}109.2 \\
109.2 \\
109.2 \\
107.9 \\
112.2 / 2 \\
109.2 \\
109.2 \\
109.2 \\
109.2 \\
107.9 \\
111.8 / 3 \\
109.3 \\
109.3 \\
109.3 \\
109.3 \\
107.9 \\
111.4 / 3 \\
109.4 \\
109.4 \\
109.4 \\
109.4 \\
108.0 \\
112.1 / 3 \\
109.2 \\
109.2 \\
109.2 \\
109.2 \\
107.9 \\
1284 \\
113 / 4 \\
108 / 5 \\
116 / 4 \\
132 / 3 \\
103 / 5 \\
106 / 6\end{array}$ & $\begin{array}{l}\text { N/2-C/2-H/2A } \\
\text { N/3-C/2-H/2B } \\
\text { N/2-C/2-H/2B } \\
\mathrm{H} / 2 \mathrm{~A} /-\mathrm{C} / 2-\mathrm{H} / 2 \mathrm{~B} \\
\mathrm{~N} / 3-\mathrm{C} / 3-\mathrm{N} / 1 \\
\mathrm{~N} / 3-\mathrm{C} / 3-\mathrm{H} / 3 \mathrm{~A} \\
\mathrm{~N} / 1-\mathrm{C} / 3-\mathrm{H} / 3 \mathrm{~A} \\
\mathrm{~N} / 3-\mathrm{C} / 3-\mathrm{H} / 3 \mathrm{~B} \\
\mathrm{~N} / 1-\mathrm{C} / 3-\mathrm{H} / 3 \mathrm{~B} \\
\mathrm{H} / 3 \mathrm{~A}-\mathrm{C} / 3-\mathrm{H} / 3 \mathrm{~B} \\
\mathrm{~N} / 4-\mathrm{C} / 4-\mathrm{N} / 1 \\
\mathrm{~N} / 4-\mathrm{C} / 4-\mathrm{H} / 4 \mathrm{~A} \\
\mathrm{~N} / 1-\mathrm{C} / 4-\mathrm{H} / 4 \mathrm{~A} \\
\mathrm{~N} / 4-\mathrm{C} / 4-\mathrm{H} / 4 \mathrm{~B} \\
\mathrm{~N} / 1-\mathrm{C} / 4-\mathrm{H} / 4 \mathrm{~B} \\
\mathrm{H} / 4 \mathrm{~A}-\mathrm{C} / 4-\mathrm{H} / 4 \mathrm{~B} \\
\mathrm{~N} / 4-\mathrm{C} / 5-\mathrm{N} / 2 \\
\mathrm{~N} / 4-\mathrm{C} / 5-\mathrm{H} / 5 \mathrm{~A} \\
\mathrm{~N} / 2-\mathrm{C} / 5-\mathrm{H} / 5 \mathrm{~A} \\
\mathrm{~N} / 4-\mathrm{C} / 5-\mathrm{H} / 5 \mathrm{~B} \\
\mathrm{~N} / 2-\mathrm{C} / 5-\mathrm{H} / 5 \mathrm{~B} \\
\mathrm{H} / 5 \mathrm{~A}-\mathrm{C} / 5-\mathrm{H} / 5 \mathrm{~B} \\
\mathrm{~N} / 4-\mathrm{C} / 6-\mathrm{N} / 3 \\
\mathrm{~N} / 4-\mathrm{C} / 6-\mathrm{H} / 6 \mathrm{~A} \\
\mathrm{~N} / 3-\mathrm{C} / 6-\mathrm{H} / 6 \mathrm{~A} \\
\mathrm{~N} / 4-\mathrm{C} / 6-\mathrm{H} / 6 \mathrm{~B} \\
\mathrm{~N} / 3-\mathrm{C} / 6-\mathrm{H} / 6 \mathrm{~B} \\
\mathrm{H} / 6 \mathrm{~A}-\mathrm{C} / 6-\mathrm{H} / 6 \mathrm{~B} \\
\mathrm{Cd} / 1-\mathrm{O} / 5-\mathrm{H} / 01 \\
\mathrm{Cd} / 1-\mathrm{O} / 5-\mathrm{H} / 02 \\
\mathrm{H} / 01-\mathrm{O} / 5-\mathrm{H} / 02 \\
\mathrm{Cd} / 1-\mathrm{O} / 6-\mathrm{H} / 03 \\
\mathrm{Cd} / 1-\mathrm{O} / 6-\mathrm{H} / 04 \\
\mathrm{H} / 03-\mathrm{O} / 6-\mathrm{H} / 04 \\
\mathrm{H} / 05-\mathrm{O} / 7-\mathrm{H} / 06\end{array}$ \\
\hline
\end{tabular}

Table 4. TG-DSC data of the complex.

\begin{tabular}{l|c|c|c|c}
\multirow{2}{*}{ Step } & \multicolumn{2}{|c|}{ TG } & \multicolumn{2}{c}{ DSC } \\
\cline { 2 - 5 } & Temp. range $\left({ }^{\circ} \mathbf{C}\right)$ & Decomp. $(\%)$ & Peak position/ ${ }^{\circ} \mathbf{C}$ & Nature of peaks \\
\hline I & 93 to 150 & $15-\left(6 \mathrm{H}_{2} \mathrm{O}\right)$ & 118 & endo \\
\hline II and III & 154 to 229 & $40-2\left(\mathrm{CH}_{2}\right)_{6} \mathrm{~N}_{4}$ & 157 and 224 & exo \\
\hline IV & 239 to 392 & Ignition & 353 & exo
\end{tabular}

In the first step, all the six hydrate molecules ( $15 \%$, calculated mass $15.42 \%)$ (four coordinated and two uncoordinated) release in between the temperature range $93-150^{\circ} \mathrm{C}$. This step is endothermic as an endothermic peak has appeared at $130^{\circ} \mathrm{C}$ in DSC curve. The second and third steps are not well separated. In these steps, HMTA moiety and perchlorate ion undergo redox reaction (ignition) in-between temperatures $154-229^{\circ} \mathrm{C}$. These two steps are exothermic as two exothermic DSC peaks appeared at temperatures $157^{\circ} \mathrm{C}$ and $224^{\circ} \mathrm{C}$, correspondingly. In these two steps, the HMTA molecules oxidize by the perchlorate oxygen, releasing heat and gases, causing weight loss and exotherms in DSC curve, and they are corresponding to all these three steps DTG peaks have been recorded. Above $300^{\circ} \mathrm{C}$ the remaining residue of the third step ignited slowly, giving a broad exothermic peak in DSC 
curve. At last, a residue corresponding to $\mathrm{CdO}$ has been left. Thus, as depicted by the above discussions, the thermolysis pattern of the complex can be given as below in which the second reaction includes the last three steps of decomposition:

$$
\begin{aligned}
& 93-150^{\circ} \mathrm{C} \\
& {\left[\mathrm{Cd}(\mathrm{HMTA})_{2}(\mathrm{H} 2 \mathrm{O})_{4}\right]\left(\mathrm{ClO}_{4}\right)_{2} .2 \mathrm{H}_{2} \mathrm{O} \underset{-6 \mathrm{H}_{2} \mathrm{O}}{\longrightarrow}\left[\mathrm{Cd}(\mathrm{HMTA})_{2}\right]\left(\mathrm{ClO}_{4}\right)_{2}} \\
& {\left[\mathrm{Cd}(\mathrm{HMTA})_{2}\right]\left(\mathrm{ClO}_{4}\right)_{2} \underset{\text { Ignition }}{\stackrel{154-229^{\circ} \mathrm{C}}{\longrightarrow}} \mathrm{CdO}+\text { Gases }}
\end{aligned}
$$

Table 5. The activation energy $\left(\mathrm{E}_{\mathrm{a}}\right)$, Arrhenius factor, and correlation coefficients $(r)$ for the isothermal decomposition of the complex.

\begin{tabular}{l|l|c|c|c|c} 
S.No. & Model [Integral form] & $\boldsymbol{r}$ & Std dev & Mean dev & $\boldsymbol{E}_{\mathbf{k J}} \mathbf{\text { mol}}$ \\
\hline 1 & Power law $\left[\alpha^{1 / 4}\right]$ & 0.9195 & 2.502 & 2.363 & 41.6 \\
\hline 2 & Power law $\left[\alpha^{2 / 3}\right]$ & 0.9204 & 2.388 & 2.255 & 41.6 \\
\hline 3 & Power law $\left[\alpha^{1 / 2}\right]$ & 0.9221 & 2.147 & 2.120 & 41.7 \\
\hline 4 & Power law $\left[\alpha^{3 / 2}\right]$ & 0.9312 & 2.015 & 1.898 & 42.5 \\
\hline 5 & Parabolic law $\left[\alpha^{2}\right]$ & 0.9349 & 1.997 & 1.880 & 42.8 \\
\hline 6 & Mampel $[-\ln (1-\alpha)]$ & 0.9508 & 1.447 & 1.350 & 47.1 \\
\hline 7 & Avrami-Erofeev $[-\ln (1-\alpha)]^{1 / 4}$ & 0.9273 & 2.334 & 2.203 & 41.9 \\
\hline 8 & Avrami-Erofeev $[-\ln (1-\alpha)]^{1 / 3}$ & 0.9424 & 1.986 & 1.869 & 46.3 \\
\hline 9 & Avrami-Erofeev $[-\ln (1-\alpha)]^{1 / 2}$ & 0.9447 & 1.794 & 1.685 & 46.5 \\
\hline 10 & Contracting sphere $\left[1(1-\alpha)^{1 / 3}\right]$ & 0.9419 & 2.131 & 2.008 & 44.4 \\
\hline 11 & Three-dimensional diffusion & 0.9509 & 2.196 & 2.069 & 46.3 \\
\hline 12 & Contracting cylinder $\left[1(1-\alpha)^{1 / 2}\right.$ & 0.9371 & 2.091 & 1.970 & 43.5 \\
\hline 13 & Prout-Tompkins $[\ln (\alpha / 1-\alpha)]$ & 0.9428 & 1.146 & 1.053 & 46.4 \\
\hline 14 & Ginstling-Brounshtein & 0.9443 & 2.651 & 2.504 & 44.4
\end{tabular}

In the request to compute activation energy ( $\left.\mathrm{E}_{\mathrm{a}}\right)$ for early thermolysis (30\% mass loss), a collection of reaction models (table 5) [50] was utilized on isothermal TG data in temperature extend $200-240^{\circ} \mathrm{C}$ (figure 4 ).

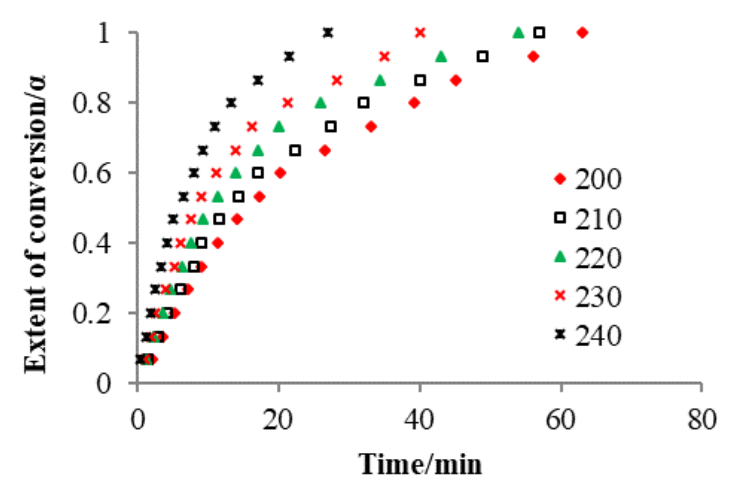

Figure 4. Isothermal TG of complex in a static air atmosphere at different temperatures.

$E_{a}$ values obtained were $\sim 44 \pm 3 \mathrm{kJmol}^{-1}$. Kinetic investigation of isothermal TG data applying isoconversional technique [51-53] regards the estimation of activation energy free of the model yet relating to the degree of change $(\alpha)$ of the complex. Figure 5 demonstrates that for a different value of $\alpha, E_{a}$ values are different. 


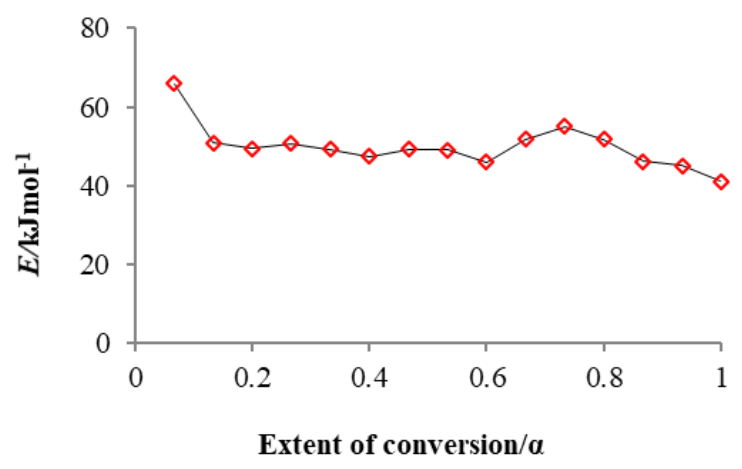

Figure 5. Variation of activation energy of thermolysis for the complex with the extent of conversion $(\alpha)$

Along these lines, without the model, isocoversional strategy is a superior way to deal with, to get dependable and predictable kinetic data which contrasted with model-fitting methods. The complex, when subjected to sudden high temperature, explodes with loud noise and smoke. To decide the activation energy of the explosion ( $\left.\mathrm{E}^{*}\right)$, an explosion delay was recorded at five unique temperatures (table 5) and observed to be $25.2 \mathrm{kJmol}^{-1}$. A graph of $\operatorname{lnDE}$ versus $1 / \mathrm{T}$ (figure 6) shows that the explosion delay does not depend exponentially on temperatures.

Table 6. Explosion delay, the activation energy for the thermal explosion $\left(E^{*}\right)$ and correlation coefficient (r)of the complex.

\begin{tabular}{|c|c|c|c|c|c|c|c|c|}
\hline \multicolumn{5}{|c|}{$D_{E} / \mathrm{s}$ at temperature $/{ }^{\circ} \mathrm{C}$} & \multirow[t]{2}{*}{$\boldsymbol{r}$} & \multirow[t]{2}{*}{$E^{*} / \mathrm{kJ} \mathrm{mol}^{-1}$} & \multirow{2}{*}{ Std. Dev. } & \multirow[t]{2}{*}{ Mean Dev. } \\
\hline $280 \pm 1$ & $300 \pm 1$ & $320 \pm 1$ & $340 \pm 1$ & $360 \pm 1$ & & & & \\
\hline 101 & 80 & 66 & 56 & 51 & 0.9937 & 25.2 & 2.235 & 2.113 \\
\hline
\end{tabular}

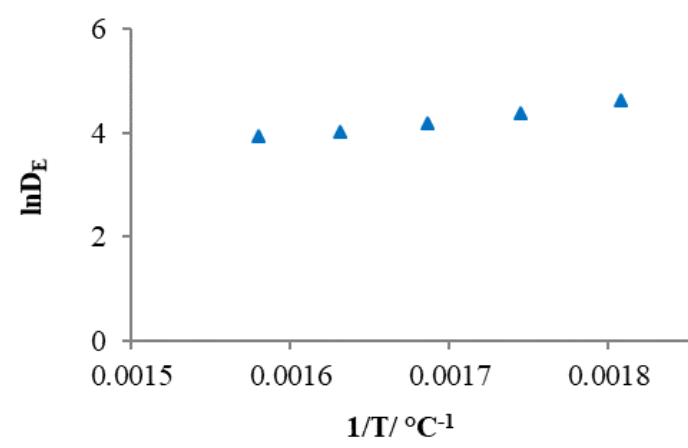

\section{Conclusions}

Figure 6. Graph of $\ln \mathrm{D}_{\mathrm{E}} \mathrm{VS} .1 / \mathrm{T}$ for the complex.

X-ray crystallography shows that the prepared complex has coordination number six. TG-DSC observations exhibit that the synthesized complex decomposes in four steps. After an initial weight loss ( $15 \%$ mass, corresponding to six water molecules) reducing group, i.e., HMTA and $\mathrm{ClO}_{4}$, undergo a redox reaction to give two exothermic peaks in DSC. The end product of thermolysis corresponds to $\mathrm{CdO}$ as a solid residue $(\sim 18 \%)$.

\section{Funding}

This research was funded by U.G.C. New Delhi, India grant number 39 -702 / 2010 (SR)".

\section{Acknowledgments}

Thanks to Secretary, Board of Management, and the Head of Department of Chemistry, D.B.S. College, Kanpur, for imparting laboratory facilities. Analytical facilities (CHN analyses, FT- 
IR, and TG-DSC analysis) supplied by SAIF, Cochin University of Science and technology are fortuitously identified.

\section{Conflicts of Interest}

The authors declare no conflict of interest.

\section{References}

1. Ahuja, I.S.; Yadava, C.L.; Tripathi, S. Coordination Polymers of Some Uranyl Salts Involving 4,4' Bipyrideyl, 4,4' -Bipyridyl N,N' -dioxide, 1,3-Bis(4-pyridyl) propane and Hexamethylenetetramine. Asian Journal of Chemistry 1989,1, 195-207.

2. Kumar, D.; Kapoor, I.P.S.; Singh, G ; Goel, N.; Singh, U.P.Preparation, characterization and thermal behaviour of polymeric complex of cadmium hexamethylenetetramine nitrate. Solid State Science 2012, 14, 495-500,https://doi.org/10.1016/j.solidstatesciences.2012.01.021.

3. Konar, S.; Mukherjee, P.S.; Drew, M.G.B.; Ribas, J.; Chaudhari, N.R.Syntheses of Two New 1D and 3D Networks of $\mathrm{Cu}(\mathrm{II})$ and $\mathrm{Co}$ (II) Using Malonate and Urotropine as Bridging Ligands: Crystal Structures and Magnetic Studies. Inorganic Chemistry 2003,42, 2545-2552,https://doi.org/10.1021/ic020549u.

4. Dalvi, A.A.; Satpathi, A.K.; Palrecha, M.M.Simultaneous determination of Pt and Rh by catalytic adsorptive stripping voltammetry, using hexamethylene tetramine (HMTA) as complexing agent. Talanta 2008, 75, 1382-1387,https://doi.org/10.1016/j.talanta.2008.01.053.

5. Singh, G.; Barnawal, B.P.; Kapoor, I.P.S.; Kumar, D.; Frohlich, R.Preparation, X-ray Crystallography, and Thermal Decomposition of Some Transition Metal Perchlorate Complexes of Hexamethylenetetramine. Journal of Physical Chemistry A2007, A111, 12972-12976, https://doi.org/10.1021/jp077278z.

6. Singh, G.; Barnawal, B.P.; Kapoor, I.P.S.; Kumar, D.; Singh, C.P.; Frohlich, R.Some transition metal nitrate complexes with hexamethylenetetramine. Journal of Thermal Analysis and Calorimetry2008,91, 971-976, https://doi.org/10.1007/s10973-007-8615-5.

7. Patil, K.C.; Verneker, V.R. Pai; Jain, S.R.Role of metal perchlorate ammines on ammonium perchlorate decomposition. Combustion and Flame 1975,25, 387-392, https://doi.org/10.1016/0010-2180(75)90110-8.

8. Stoner, C.E.; Haggerty J.B.S.; Rheingold, A.L; Brill, T.B.Thermal decomposition of energetic materials. 55. Metal Complexes of Diamioglyoxime as Potential Burn Rate Modifiers in composite propellants. Propellants, Explosives, Pyrotechnics 1992, 17, 82-87,https://doi.org/10.1002/prep.19920170207.

9. Sonawane, S.H.; Gore, G.M.; Polke, B.G.; Nazare, A.N.; Asthana, S.N. Transition Metal Carbohydrazide Nitrates: Burn-rate Modifiers for Propellants. Defence Science Journal 2006, 56, 391-398, https://doi.org/10.14429/dsj.56.1905.

10. Singh, G.; Kapoor, I.P.S.; Pandey, D.K. Hexammine metal perchlorates as energetic burning rate modifiers. Journal of Energetic Materials 2002, 20, 223-244, https://doi.org/10.1080/07370650208244822.

11. Singh, G.; Pandey, D.K. Studies on energetic compounds part 27: kinetics and mechanism of thermolysis of bis(ethylenediamine) metal nitrate and their role in the burning rate of solid propellants. Propellants, Explosives, Pyrotechnics 2003, 28, 231-239, https://doi.org/10.1002/prep.200300010.

12. Singh, G.; Pandey, D.K. Studies on energetic compounds: part 40, Kinetics of thermal decomposition of some bis(propylenediamine) metal perchlorate complexes. Journal of Thermal Analysis and Calorimetry 2005, 82, 353-360, http://dx.doi.org/10.1007/s10973-005-0902-4.

13. Topalian, Z. Nanostructured Transition Metal Oxides in Cleantech Application: Gas Sensors, Photocatalysis, Self-cleaning Surfaces Based on $\mathrm{TiO}_{2}, \mathrm{WO}_{3}$ and $\mathrm{NiO}$. (Doctoral dissertation). Uppsala: Acta Universitatis Upsaliensis 2011, 69, 809.

14. Bresser, D.; Muller, F.; Fiedler, M.; Krueger, S.; Kloespsch, R.; Baither, D.; Winter, M.; Paillaered, E.; Passerini, S. Transition-metal-doped zinc oxide nanoparticles as a new lithium-ion anode material. Chemistry of Materials 2013, 25, 4977-4985,https://doi.org/10.1021/cm403443t.

15. Gillaspie, D.T.; Robert, C.T. Anne, C.D.Metal-oxide films for electrochromic applications: present technology and future directions. Journal of Materials Chemistry 2010,20, 95859592,https://doi.org/10.1039/C0JM00604A.

16. Shen, S.M.; Chen, S.; Wu, B.H.The thermal decomposition of ammonium perchlorate (AP) containing a burning-rate modifier. Thermochimica Acta 1993,223, 135-143,https://doi.org/10.1016/00406031(93)80128-W.

17. Verdejo, M.C.; Camrada, M.B.; Arroyo, J.L.; Povea, P.; Carreno, G.; Manriquez, J.M. Effect of the homoand heterobimetallic compounds derived from s-indacene on the thermal decomposition of ammonium perchlorate. Journal of Thermal Analysis and Calorimetry 2018, 131, 353361,https://doi.org/10.1007/s10973-017-6534-7.

18. Cheng, J.; Zuliang, Z.; Li, L.L.; Zhao, F.; Xu, S. Catalytic reaction of ammonium perchlorate with energetic cobalt complex of 2,6-diamino-3,5-dinitropyrazine-1-oxide during thermal decomposition process. Journal of Thermal Analysis and Calorimetry 2017, 129, 1875-1885, https://doi.org/10.1007/s10973-017-6263-y. 
19. Lu, L.P.; Xue-Chuan, Lv.; Gao, X.H.; Tan, Z.C. Low-temperature molar heat capacities, thermodynamic properties and crystal structure of $\mathrm{Cu}\left(\mathrm{C}_{3} \mathrm{~N}_{2} \mathrm{H}_{4}\right)_{4}\left(\mathrm{ClO}_{4}\right)_{2}$. Journal of Thermal Analysis and Calorimetry 2018,131, 15-23, https://doi.org/10.1007/s10973-016-5697-y.

20. Luo, G.H.; Gao, X.H.; Pan, L.; Lv, X.C.; Tan, Z.C. Low-temperature molar heat capacities and thermodynamic properties of a new rare earth complex $\operatorname{Er}_{2}\left(\mu_{2_{2}}\right.$ Gly $)_{6}\left(\mathrm{H}_{2} \mathrm{O}\right)_{4} \cdot \mathrm{Na}_{2}\left(\mathrm{ClO}_{4}\right)_{8}\left(\mathrm{H}_{2} \mathrm{O}\right)_{2} \cdot 4 \mathrm{H}_{2} \mathrm{O}$.Journal of Thermal Analysis and Calorimetry 2016,126, 871879, https://doi.org/10.1007/s10973-016-5449-z.

21. Yufanyi, D.M.; Ondoh,A.M.; Tendo,J.F.; Mbadcam, K.J. Effect of decomposition temperature on the crystallinity of $\alpha-\mathrm{Fe}_{2} \mathrm{O}_{3}$ (Hematite) obtained from an Iron(III)-Hexamethylenetetramine Precursor. American Journal of Chemistry 2015, 5, 1-9.

22. Tabong, C.D.; Ondoh,A.M.; Yufanyi,D.M.; Foba, J. Cobalt(II) and zinc(II) complexes of hexamethylenetetramine as single source precursors for their metal oxide nanoparticles. Journal of Materials Science Research 2015,4, 70-81, http://dx.doi.org/10.5539/jmsr.v4n4p70.

23. Mbonu I.J.; Okpalaezinne, N.P.Synthesis, characterization and biological activity of mixed ligands complex of Co(II) ions with succinic acid and hexamethylenetetramine. Chemistry and Materials Research 2015, 7 , $52-55$.

24. Tabong, C.D.; Yufanyi, D.M.; Paboudam,A.G.; Nono,K.N.; Eni, D.B.; Agwara, M.O. Synthesis, crystal structure, and antimicrobial properties of [diaquabis (hexamethylenetetramine) diisothiocyanato- $\kappa \mathrm{N}$ ] nickel (II) complex. Advances in Chemistry 2016, 2016.

25. Kumar, D.; Kapoor, I.P.S.; Singh, G.X-ray crystallography and thermolysis of ammonium perchlorate and protonated hexamethylenetetramine perchlorate prepared by newer methods. International Journal of Energetic Materials and Chemical Propulsion 2010, 9, 549560,https://doi.org/10.1615/IntJEnergeticMaterialsChemProp.2011002679.

26. Zhimin, Li ; Zhou, Z.; Zhang, T.; Tang, Z.; Yang, L.; Zhang, J.Energetic transition metal $(\mathrm{Co} / \mathrm{Cu} / \mathrm{Zn})$ imidazole perchlorate complexes: Synthesis, structural characterization, thermal behavior and nonisothermal kinetic analyses. Polyhedron 2012, 44, 59-65,https://doi.org/10.1016/j.poly.2012.06.030.

27. Ilyushin,M.A.; Tselinskiy,I.V.; Smirnove, A.V.; Shugalei, I.V. Physicochemical properties and laser initiation of a copper perchlorate Complex with 3(5)-hydrazino-4-amino-1,2,4-triazole (HATr) as a ligand. Central European Journal of Energetic Materials 2012, 9, 3-16.

28. Ilyushin,M.A.; Alieksandrova, M.A.; Bachurina, I.V.; Smirnov, A.V. Taselinskii, I.V. Synthesis and properties of an energetic complex pentaamminecobalt (III) perchlorate, with 4-amino-1,2,4-triazole as ligand. Russian Journal of Applied Chemistry 2010, 83, 92-96,https://doi.org/10.1134/S1070427210010180.

29. Singh, G.; Kapoor, I.P.S.; Kumar, D.; Singh, U.P.; Goel, N. Preparation, X-ray crystallography and thermal decomposition of transition metal perchlorate complexes with perchlorate and 2,2'-bipyridyl ligands, Inorganica Chimica Acta 2009, 362, 4091-4098,https://doi.org/10.1016/j.ica.2009.06.003.

30. Kokunov, Y.V.; Gorbunova, Y.E.; Razgonyaeva, G.A.; Kozyukhin, S.A.Synthesis, crystal structures, and luminescence spectra of the coordination compounds of cadmium(II) iodide with hexamethylenetetramine, Russian Journal of Coordination Chemistry 2012,38, 661,https://doi.org/10.1134/S1070328412100089.

31. Yolcu, Z. Cadmium(II) chloride complex containing 1-vinylimidazole ligand: structural, spectroscopic and thermal properties. Journal of Science and Technology 2020, 13, 25-32, https://doi.org/10.18185/erzifbed.566231.

32. Smirnovaab, K.S.; Liderab, E.V.; Sukhikh T.S.; Berezina, A.S.; Potapova, A.S. Cadmium coordination compounds with flexible ligand 1,3-bis(1,2,4-triazol-1-yl)propane: Synthesis, structure and luminescent properties.Polyhedron 2020, 177, https://doi.org/10.1016/j.poly.2019.114286.

33. Nath, J.; Tarai, A.; Baruah, J.B. Copper(II), zinc(II), and cadmium(II) formylbenzoate complexes: reactivity and emission properties. ACS Omega2019, 4, 18444-18455, https://doi.org/10.1021/acsomega.9b02779.

34. Klose, J.; Severin, T.; Hahn, P.; Jeremies, A.; Bergmann, J.; Fuhrmann, D.; Griebel, J.; Abel, B.; Kersting, B. Coordination chemistry and photoswitching of dinuclear macrocyclic cadmium-, nickel-, and zinc complexes containing azobenzene carboxylato co-ligands. Beilstein Journal of Organic Chemistry2019, 15, 840-851, https://doi.org/10.3762/bjoc.15.81.

35. Marchenko, R.D.; Lysova, A.A.; Samsonenko, D.G.; Dybtsev, D.N.; Potapov, A.S. Synthesis, structural diversity, luminescent properties and antibacterial effects of cadmium(II) and silver(I) coordination compounds with bis(1,2,3-benzotriazol-1-yl)alkanes. Polyhedron2020, 177, https://doi.org/10.1016/j.poly.2019.114330.

36. Waheed, E.J.; Farhan, M.A.; Hameed, G.F.Synthesis and characterization of new manganese(II), cobalt(II), cadmium(II) and mercury(II) complexes with ligand [N-(3-acetylphenylcarbamothioyl)-2- chloroacetamide] and their antibacterial studies. The 1st International Scientific Conference on Pure Science IOP Conf. Series: Journal of Physics: Conf. Series 1234 IOP Publishing, 2019; https://doi.org/10.1088/17426596/1234/1/012096.

37. Abyar, S.;Khandar, A.A.; Salehi, R.; Hosseini-Yazdi, S.A.; Alizadeh, E.; Mahkam, M.; Jamalpoor, A.; White, J.M.; Shojaei, M.; Aizpurua-Olaizola, O.; Masereeuw, R.; Janssen, M.J. In vitro nephrotoxicity and 
anticancer potency of newly synthesized cadmium complexes. Scientific Reports 2019, 9, https://doi.org/10.1038/s41598-019-51109-9.

38. Dubey, R.P.; Patel, U.H.; Pandya, S.B.; Chaudhary, K.P.; Socha, B.N. Cadmium complex of sulfathiazole dihydrate with secondary ligand pyridine: structure, DFT studies, Hirshfeld surface analysis and antimicrobial activity. Indian Journal of Physics 2020, https://doi.org/10.1007/s12648-019-01680-8.

39. Dou, X.; Li, G.; Zhang, W.; Lu, F.; Luo, D.; Liu, W. Fast production of zinc-hexamethylenetetramine complex microflowers as an advanced sulfur reservoir for high-performance lithium-sulfur batteries. Journal of Materials Chemistry A2020, 8, 5062-5069, https://doi.org/10.1039/C9TA12573F.

40. Qiao, X.; Ge, Y.; Li, Y.; Niu, Y.; Wu, B. Preparation and analyses of the multifunctional properties of 2D and 3D MOFs constructed from copper(I) halides and hexamethylenetetramine. ACSOMEGA 2019, 4, 12402-12409, https://doi.org/10.1021/acsomega.9b01356.

41. Nibha; Baranwal, B.P.; Singh, G.; Singh, C.P.; Daniliuc, Constantin G.; Soni, P.K.; Nath, Y. Kinetics of thermolysis of lanthanum nitrate with hexamethylenetetramine: Crystal structure, TG-DSC, impact and friction sensitivity studies, Part-96. Journal of Molecular Structure 2014, 1076, 539-545, https://doi.org/10.1016/j.molstruc.2014.08.009.

42. Nakamoto, K. Infrared and Raman Spectra of inorganic and coordination compounds. New York: Wiley, 1978; https://doi.org/10.1002/0470027320.s4104.

43. Robert, C.W. Handbook of Physics and Chemistry. Florida: CRC Press, Volume 66, 1996.

44. Miller, F.A.; Wilkins, C.H. Infrared spectra and characteristic frequencies of inorganic ions. Analytical Chemistry Handbook of Physics and Chemistry, Florida: CRC Press 1952, 24, 1253-1294, https://doi.org/10.1021/ac60068a007.

45. Hooft, R. Data collection software. COLLECT, Nonius, B.V. Delt, The Netherlands, 1998.

46. Otowinowaski, Z.; Minor, W. Processing of X-ray diffraction data collected in oscillation mode. Methods Enzymol 1997, 276, 307-326, https://doi.org/10.1016/S0076-6879(97)76066-X.

47. Sheldrick, G.M. A Short History of SHELX. Acta Crystallographica A 2008,64, 112122,https://doi.org/10.1107/S0108767307043930.

48. Keller, E.; Schakal, A Computer Program for the graphic representation of molecular and crystallographic models. University of Freiburg, Germany 1997.

49. Singh, G.; Singh, R.R. Indigenously fabricated apparatus for thermogravimetric analysis. Research Industry 1978, 23, 92-103.

50. Brown, M.E.; Dollimore, D.; Galway, A.K. Reactions in the solid state, comprehensive chemical kinetics. Amsterdam, The Netherlands: Elsevier, Volume 22, 1997.

51. Vyazovkin, S.; Wight, C.A. Isothermal and nonisothermal reaction kinetics in solids: in search of ways toward consensus. Journal of Physical Chemistry A 1997, 101, 82798284,https://doi.org/10.1021/jp971889h.

52. Vyazovkin, S.; Wight, C.A. Model-free and model-fitting approaches to kinetic analysis of isothermal and nonisothermal data. ThermochimicaActa1999, 53, 340-341, https://doi.org/10.1016/S0040-6031(99)002531 .

53. Singh, C.P.; Singh, A.; Rao, D.P. Thermal decomposition and their kinetics of mercury(ii) perchlorate complex with 4-aminopyridine and water. Letters in Applied NanoBioScience 2019, 8, 649-653, https://doi.org/10.33263/LIANBS83.649653.

54. Singh, G.; Kapoor, I.P.S.; Vasudeva, S.K. Thermolysis of AP-PS additive mixtures. Indian Journal of Technology 2004, 29, 589-594. 